\title{
Effect of Maltodextrin Reduction and Native Agave Fructans Addition on the Rheological Behavior of Spray-Dried Juices
}

\author{
Darvin Ervey Jimenez-Sánchez, \\ Montserrat Calderón-Santoyo, \\ Laetitia Picart-Palmade, \\ Pedro Ulises Bautista Rosales, \\ Julio Cesar Barros-Castillo and \\ Juan Arturo Ragazzo-Sánchez \\ Additional information is available at the end of the chapter \\ http://dx.doi.org/10.5772/intechopen.75758
}

\begin{abstract}
Agave fructans have thermal protective and encapsulating properties as well as technological functions as stabilizers. The effect of the combination of maltodextrin $10 \%[\mathrm{w} / \mathrm{v}]$ and native agave fructans in concentrations of 0,2 , and $4 \%[\mathrm{w} / \mathrm{v}]$ on the rheological properties and microstructure, of spray-dried chayote, carrot, mango and pineapple powders was evaluated. The flow behavior was analyzed in a simple shear flow and low-cutting speed in the range of 5-200 s ${ }^{-1}$. The experimental data of fresh or reconstituted juices were fitted to different flow models such as Newtonian, Bingham, and Ostwald-de-Waele. The flow behavior of all juices can be described by the Bingham model with low plastic viscosities; the addition of fructans and the step of spray drying had no significant influence on the plastic viscosity of juices as compared to fresh juices.
\end{abstract}

Keywords: fructans, spray drying, rheology, microstructure, Newtonian fluid

\section{Introduction}

Pineapple, mango, carrot and chayote are highly regarded due to their taste and nutritional value. All these fruits are recognized because of their high content in antioxidants such as 
polyphenols, carotenoids and vitamin C. Chayote is also an important source of folic acid. There is an increasing interest in highly nutritious and instant foods, which is why the concentrated juice powder of these fruits could be an excellent and profitable option for consumption. In this way, chayote is mainly produced in Mexico and unknown in most countries. Due to the physical characteristics of the different types of fruit and the environmental conditions in the growing regions, large amounts of the harvested fruits fall short of the minimum quality standards for direct use and result in significant losses.

In recent years, new processes have been under development in order to achieve commercialization for fruit that fails to meet quality standards - the idea is to create products higher in quality and with greater added value. In this sense, the production of fruit juice powders is a better alternative for the use of raw material that fails to meet quality standards for exportation. In the processing of fruit juice, many variables exist that can lead to changes in the final product quality [1]. Rheological properties play an important role in the handling and processing, quality control and sensory evaluation of various foods [2]. The determination of rheological properties such as viscosity is of great importance in the prediction of heat and mass coefficients as well as for the design or development of heat transfer equipment and mass in the fruit juice industry [3]. Operational effects, such as concentration by evaporation, reverse osmosis, pumping and homogenization, are due to variations in viscosity [3]. In addition, factors such as the variety or maturity of the fruit and the treatment applied to fruit juice affect the viscosity of a reconstituted juice, so that the preference and acceptability of the consumer will be influenced by these factors [1, 4, 5]. Spray-drying is an alternative process for products which are sensitive to heat and has been used successfully in fruit juices [6]; the result is a product that has acceptable sensory characteristics and stability for storage.

In order to increase the glass transition temperature ( $\mathrm{Tg}$ ), the addition of thermoprotective additives such as maltodextrin is necessary to guarantee an adequate control of the spray drying process in fruit juices and the quality of the products obtained. The average aggregate amount has been reported between $30 \%$ and $75 \%(\mathrm{w} / \mathrm{v})$; however, an excess of these generates increases in viscosity $[7,8]$, which stands in function of the total solids content of the particular juice to be processed. Carrier agent usually used in spray drying of fruit juices are carbohydrate based, such as maltodextrins and gums, mainly due to their high solubility, low viscosity, which are important conditions for the spray-drying process [9]. The production of fruit powders presents a challenge in the reduction of the viscosity of the juice of feeding, for the improvement of the drying, handling and storage. The presence of fructose, glucose and sucrose which are low molecular weight sugars as well as some organic acids in the fruit have changes in the viscosity of the fruit powder and the reconstituted.

Recent studies have attributed agave fructans with thermal protective and encapsulating properties, as well as technological functions as stabilizers [10]. Fructans are rich in fructose polymers with a terminal glucose and are composed of fructose units and terminal glucose unit linked by $\beta-(2 \rightarrow 1)$ and $\beta-(2 \rightarrow 6)$ links [11]. The most common inulin type fructans are from chicory roots (Cichorium intybus). On the other hand, levan-type fructans are present in grasses and cereals as well as those produced by bacteria [12]; however, this levan fructans are 
rarely commercially available. At the same time, inulin-type fructans are widely used as food ingredients because of their gelling and thickening capacity, its ability for replace fat by up to $100 \%$ [13] as well as substitute of other carbohydrates to reduce the calories of some foods such as ice creams, dairy products and baked goods [11, 14].

Fructans are widely distributed in plants. They perform similar functions as dietary fiber and indigestible in the gastro-intestinal tract. As polymers, they have high molecular weight, increase amount of solids, provide no flavor or color, in general, they have functional properties that are excellent candidates as carrier agents. Botrel et al. [15] demonstrated that fructans have favorable effects on the microencapsulation of fish oil when used as carrier agents, favoring the reduction of particle size, high efficiency in microencapsulation and a decrease in bulk density. Chávez et al. [16] concluded that the thermal stability of agave fructans during the spray-drying process gives them the ability to be used as carrier agents.

Linear fructans show the tendency to form gels while branched fructans promote the formation of solutions [10]. In this sense, it has been reported that levan-type fructans interact with the membranes of phospholipids, which causes the properties of the surface of the acid mixtures to be strongly affected [17].

The reconstituted powders are fluids that can be classified according to their response to deformation in the linear (LVR) and non-linear viscoelastic (n-LVR) region. In particular, large amplitude oscillatory shear (LAOS) deformation permits varying experiments depending on whether suitable conditions for examining the material response within LVR are present and to obtain additional information in n-LVR. LVR is related to the structural arrangement, while n-LVR is associated with the mechanical response when food structure has been mostly deformed [18]. The n-LVR is more related to consumer perception than LVR [19].

Currently, few reports on the use of agave fructans as additives in the spray-drying process of fruit, or their use in the reduction of conventionally used materials, such as MD exist. In this sense, the objective of this study was to evaluate the effect of adding agave fructans and maltodextrin DE 10 on rheology in spray-dried chayote (Sechium edule), pineapple (Ananas comosus), carrot (Daucus carota) and mango (Mangifera indica) juices.

\section{Fruit powder rheology}

\subsection{Raw materials}

Chayote, carrot, mango and pineapple fruit in consumption degree of ripeness were obtained in Tepic, Nayarit and subsequently washed and disinfected in a sodium hypochlorite solution $(\mathrm{NaClO})$ at $200 \mathrm{ppm}(0.02 \%)$. Then, they were peeled, and the juice of these fruits was obtained using a conventional extractor. Maltodextrin DE10 or native agave fructans were added by homogenization using an electric laboratory homogenizer (PRO Scientific. Inc. 300 PC) at $350 \mathrm{rpm}$ during $15 \mathrm{~min}$ and filtered in a No. 50 filter sieve. One liter of homogenized juice was used for each test. 


\subsection{Spray drying}

A pilot dryer (model LPG-5, CIMA Industries Inc.) equipped with a rotatory nozzle was used for the spray-drying process with a feed rate of $15 \mathrm{~mL} \cdot \mathrm{min}^{-1}, 2.5$ bar, a juice feed temperature of $25^{\circ} \mathrm{C}$, air inlet rate of $9.4 \mathrm{~m} / \mathrm{s}$ and temperature of $120^{\circ} \mathrm{C}$. Maltodextrin was added to reach a final concentration of $10 \%(\mathrm{~m} / \mathrm{v})$. Fructans were added to a concentration of $0.2 \%$ or $4 \%$. The inlet temperature and maltodextrin concentrations were determined in preliminary studies. Total solids were determined in fresh chayote, carrot, mango and pineapple juices; these parameters were taken as a reference for rehydration. A mass balance was performed to determinate the quantity of water necessary to reconstitute the powder with total solids content similar (TSS) to fresh juice.

\subsection{Rheological properties of juices}

The rheometric measurements were carried out with a controlled stress rheometer (Model AR-G2 TA Instruments with Software Trios v4.0.1) using concentric cylinder geometry [exterior cylinder diameter $21.96 \mathrm{~mm}$, interior cylinder diameter $20.38 \mathrm{~mm}$, height $59.50 \mathrm{~mm}$ ], gap $500 \mu \mathrm{m}$, a constant temperature of $25^{\circ} \mathrm{C}$, maintained in a circulating water bath and a AG2 heater. The flow behavior was analyzed in a simple shear flow, low cutting speed in a range of 5-200 s$~ s^{-1}$. Juices were reconstituted based on the total soluble solids of the fresh juice. The experimental data of fresh or reconstituted juices were fitted to different flow models such as Newtonian (Eq. 1), Bingham (Eq. 2) and Ostwald-de-Waele Power Law model (Eq. 3).

$$
\begin{gathered}
\tau=\eta \dot{\gamma} \\
\tau-\tau_{0}=\eta \dot{\gamma} \\
\tau=K \dot{\gamma}^{\eta}
\end{gathered}
$$

where $\tau$ is the shear stress $[\mathrm{Pa}], \dot{\gamma}$ is the shear rate $\left[\mathrm{s}^{-1}\right], \eta$ is the viscosity (Pa.s), $\eta^{\prime}$ is the plastic viscosity (Pa.s), $\tau_{0}$ is the yield stress $(\mathrm{Pa}), \mathrm{K}$ is the consistency index $\left(\mathrm{Pa}^{1 / 2} \mathrm{~s}^{\mathrm{n}}\right)$ and $\mathrm{n}$ is the flow behavior index.

The best rheological model for describing the flow behavior of juices was selected by comparing the value of correlation coefficient, $R^{2}$.

\subsection{Rheological analysis}

Figure 1 represents the flow curve of reconstituted juices containing three different concentrations of native agave fructans 0.2 and $4 \%$. As can be observed from the figure, the flow curves at the three concentrations demonstrate an initial yield stress, indicating the presence of entangled rehydrated powders which prevents the free flow of the juices at zero shear rates. Similar flow curves were observed in the three concentrations of fructans. Figure 1 shows 


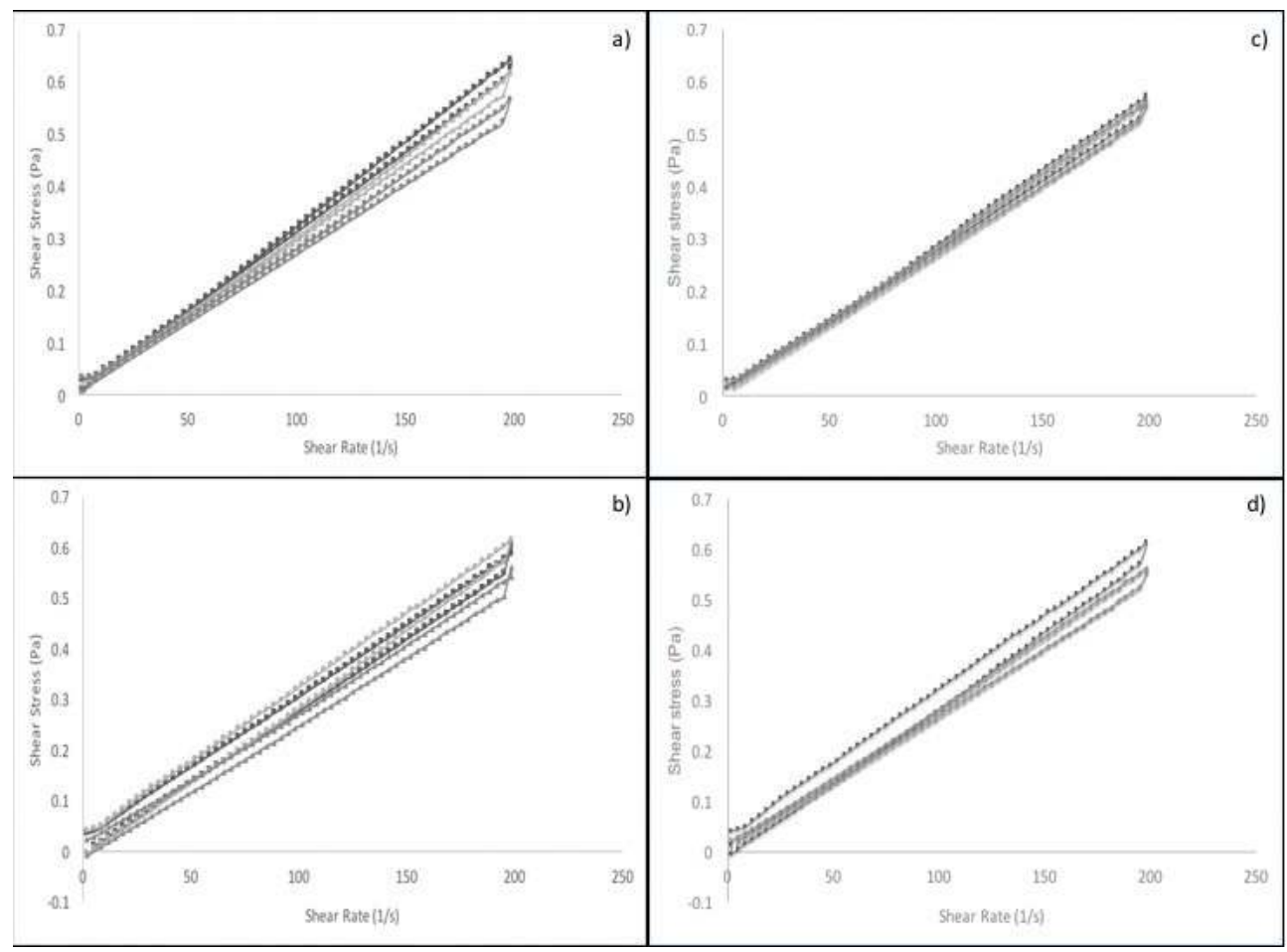

Figure 1. Flow behavior index curves of reconstituted chayote (a), pineapple (b), carrot (c), and mango (d) powders $0 \%$ FT, [O] 2\% FT, [A] $4 \%$ FT. FT: Fructanos.

in the curves flow a Newtonian behavior (viscosity independent of the shear rate) for all the concentrations of fructans studied. In this sense, shear thinning behavior is characterized for a viscosity decrease with the shear rate due to structure destruction or a new structure formation. In this study, the concentrations of fructans were below $5 \%$, so it is important to mention that for $\mathrm{C}_{\text {fructan }} \leq 30 \%[\mathrm{w} / \mathrm{v}$ ] [which were measured in a double wall Couette geometry], and at shear rates smaller than $70 \mathrm{~s}^{-1}$ shear thinning was detected followed by shear thickening at shear rates higher than $270 \mathrm{~s}^{-1}$ in accordance with Ponce et al. [20].

Arvidson et al. [12] found shear thinning for aqueous levan polysaccharide solutions of $30 \%$ $[\mathrm{w} / \mathrm{v}]$ and were measured at $20^{\circ} \mathrm{C}$. The double wall Couette-type geometry presents secondary flow formation or Taylor vortices at higher shear rates, behaving turbulently as a flow type. The observed shear thickening behavior at high shear rates is attributed to the formation of instabilities of hydrodynamic flow [21,22].

This phenomenon has been studied predicting the stress near to the wall with the theoretical analysis of Stuart [22, 23]. Others authors have reported hydrodynamic instabilities such as Taylor-Couette Vortices in Newtonian fluids [23] and viscoelastics fluids [24, 25]. Macias et al. [26] observed flow instabilities at shear rates higher than $250 \mathrm{~s}^{-1}$ for water in Double 
wall Couette-type geometry. The shear thinning observed at low fructans concentration $\left(\mathrm{C}_{\text {fructans }} \leq 30 \%[\mathrm{w} / \mathrm{v}]\right)$ could be due to these flow instabilities, since the viscosity of agave solutions is near to the water viscosity.

The increase in viscosity is explained based on the transition of non-entangled fructan chains, however, an increase in the fructans concentration produce a greater amount of entanglements. The two slope changes they present themselves at medium concentration regimen at $\mathrm{C}_{\text {fructans }}=35 \%[\mathrm{w} / \mathrm{v}]$ which are related to the overlap chains concentration. At higher concentrations at $\mathrm{C}_{\text {fructans }}=70 \%[\mathrm{w} / \mathrm{v}]$, the solution behaves like a weak gel where high entanglements between fructan chains are detected. In solutions of linear polymers diluted with good solvents the dependence of $\eta 0$ with concentration should be $\eta \approx \mathrm{C}_{\text {fructans }} 4.7$ [27]. Nevertheless, an increase in the concentration of polysaccharides causes the addition in the values of the exponent in the law of viscosity scale. Therefore, the value of the power law generates a screen in the understanding of the structure of the solution.

At $30^{\circ} \mathrm{C}$, the agave fructan solutions exhibit a Newtonian behavior, this for samples with concentrations $\leq 80 \%[\mathrm{w} / \mathrm{v}]$. In higher concentrations, the formation of a highly viscous solution is observed, so that the system at temperatures between 25 and $30^{\circ} \mathrm{C}$ shows a shearing dilution behavior; however, at high temperatures, there is a shear thickening [20]. The effect of fructan concentration on viscosity was similar to that of fructose or sucrose solutions. This confirms that the dependence of rheology on fructan concentration is closer to that of low molecular weight monosaccharides than to that of high molecular weight polysaccharides, as was proposed by Martínez-Padilla [28].

Table 1 shows the fitted parameters of the Newtonian, Bingham and Power Law rheological models for chayote, carrot, mango and pineapple fresh or reconstituted juices with different content of fructans. For all the reconstituted juices, the best adjustment of flow data was obtained with the Bingham model, values of $R^{2}$ ranged between 0.9992 and .9999 . These results are in agreement with those of Shamsudin et al. [29] who found that the flow curves of Yankee pineapple juices were described by the Bingham model.

FT: fructans, N/A: no additives. All samples contain 10\% maltodextrin. Note: similar letters no significant differences. Different letters significant differences $(p>0.05)$.

Bingham model describes plastic fluid that behaves as a rigid body at low stresses but flows as a viscous fluid at high stress. Then this type of fluid is characterized by a yield stress and a plastic viscosity. These parameters were statistically compared in Table 2 for each formulation of juices. Whether for pineapple, carrot, mango or chayote juices, the addition of maltodextrin $(10 \%[\mathrm{w} / \mathrm{v}])$ and fructans $(0-4 \%[\mathrm{w} / \mathrm{v}])$ and the step of spray-drying had no significant influence on the plastic viscosity of juices as compared to fresh juices. Moreover, all the considered juices (Table 1) presented a low plastic viscosity that ranged from 0.0026 to $0.0030 \mathrm{~Pa}$.s at $25^{\circ} \mathrm{C}$. In contrast, yield stresses were impacted by the addition of maltodextrin, fructans or by the step of spray drying. Yield stress values were correlated to the presence and the degree of entanglement of colloids in fluids. For chayote and carrot juices, the addition of maltodextrin decreases significantly the value of the yield stress 


\begin{tabular}{|c|c|c|c|c|c|c|c|c|c|}
\hline \multicolumn{2}{|l|}{ Sample } & \multicolumn{2}{|c|}{ Newtonian } & \multicolumn{3}{|c|}{ Bingham } & \multicolumn{3}{|c|}{ Power Law } \\
\hline & & \multirow[t]{2}{*}{ 『ท } & \multirow[t]{2}{*}{$\mathbf{R}^{2}$} & & \multirow[t]{2}{*}{ खृत् } & \multirow[t]{2}{*}{$\mathbf{R}^{2}$} & \multirow[t]{2}{*}{$n$} & \multirow[t]{2}{*}{ K } & \multirow[t]{2}{*}{$\mathbf{R}^{2}$} \\
\hline & & & & Chayote & & & & & \\
\hline \multirow{4}{*}{ Fresh } & $\begin{array}{c}\mathrm{N} / \\
\mathrm{A}\end{array}$ & 0.0030 & 0.9974 & $0.0158^{\mathrm{a}}$ & 0.0028 & 0.9996 & 0.8225 & 0.0069 & 0.9815 \\
\hline & $\begin{array}{l}0 \% \\
\text { FT }\end{array}$ & 0.0029 & 0.9996 & $0.0028^{b}$ & 0.0029 & 0.9997 & 0.8981 & 0.0046 & 0.9890 \\
\hline & $\begin{array}{l}2 \% \\
\text { FT }\end{array}$ & 0.0028 & 0.9992 & $0.0064^{c}$ & 0.0028 & 0.9996 & 0.8903 & 0.0047 & 0.9924 \\
\hline & $\begin{array}{l}4 \% \\
\text { FT }\end{array}$ & 0.0029 & 0.9991 & $0.0082^{c}$ & 0.0028 & 0.9997 & 0.8794 & 0.0050 & 0.9913 \\
\hline \multirow[t]{3}{*}{ Reconstituted } & $\begin{array}{l}0 \% \\
\text { FT }\end{array}$ & 0.0032 & 0.9995 & $0.0041^{b}$ & 0.0032 & 0.9997 & 0.9393 & 0.0043 & 0.9967 \\
\hline & $\begin{array}{l}2 \% \\
\text { FT }\end{array}$ & 0.0031 & 0.9991 & $0.0040^{\mathrm{b}}$ & 0.0030 & 0.9992 & 0.9260 & 0.0043 & 0.9961 \\
\hline & $\begin{array}{l}4 \% \\
\text { FT }\end{array}$ & 0.0028 & 0.9985 & $0.0094^{c}$ & 0.0027 & 0.9994 & 0.8965 & 0.0046 & 0.9953 \\
\hline \multicolumn{10}{|c|}{ Pineapple juice } \\
\hline \multirow{4}{*}{ Fresh } & $\begin{array}{c}\text { N/ } \\
\text { A }\end{array}$ & 0.0030 & 0.9940 & $0.0252^{\mathrm{a}}$ & 0.0028 & 0.9999 & 0.9961 & 0.0029 & 0.9997 \\
\hline & $\begin{array}{l}0 \% \\
\text { FT }\end{array}$ & 0.0031 & 0.9912 & $0.0306^{\mathrm{b}}$ & 0.0028 & 0.9999 & 0.7795 & 0.0088 & 0.9878 \\
\hline & $\begin{array}{l}2 \% \\
\text { FT }\end{array}$ & 0.0031 & 0.9875 & $0.0366^{\mathrm{b}}$ & 0.0028 & 0.9999 & 0.7516 & 0.0103 & 0.9849 \\
\hline & $\begin{array}{l}4 \% \\
\text { FT }\end{array}$ & 0.0032 & 0.9819 & $0.0441^{\mathrm{b}}$ & 0.0028 & 0.9999 & 0.7211 & 0.0121 & 0.9815 \\
\hline \multirow[t]{3}{*}{ Reconstituted } & $\begin{array}{l}0 \% \\
\text { FT }\end{array}$ & 0.0030 & 0.9945 & $0.0237^{a}$ & 0.0028 & 0.9999 & 0.8430 & 0.0064 & 0.9960 \\
\hline & $\begin{array}{l}2 \% \\
\text { FT }\end{array}$ & 0.0032 & 0.9920 & $0.0302^{\mathrm{b}}$ & 0.0029 & 0.9999 & 0.8305 & 0.0072 & 0.9968 \\
\hline & $\begin{array}{l}4 \% \\
\text { FT }\end{array}$ & 0.0027 & 0.9988 & $0.0073^{c}$ & 0.0027 & 0.9994 & 0.9309 & 0.0037 & 0.9955 \\
\hline \multicolumn{10}{|c|}{ Carrot juice } \\
\hline \multirow{4}{*}{ Fresh } & $\begin{array}{c}\mathrm{N} / \\
\mathrm{A}\end{array}$ & 0.0032 & 0.9921 & $0.0174^{\mathrm{a}}$ & 0.0030 & 0.9932 & 0.8125 & 0.0078 & 0.9918 \\
\hline & $\begin{array}{l}0 \% \\
\text { FT }\end{array}$ & 0.0029 & 0.9913 & $0.0045^{b}$ & 0.0032 & 0.9897 & 0.8811 & 0.0055 & 0.9812 \\
\hline & $\begin{array}{l}2 \% \\
\text { FT }\end{array}$ & 0.0027 & 0.9991 & $0.0056^{c}$ & 0.0030 & 0.9846 & 0.8845 & 0.0048 & 0.9829 \\
\hline & $\begin{array}{l}4 \% \\
\text { FT }\end{array}$ & 0.0028 & 0.9956 & $0.0072^{c}$ & 0.0031 & 0.9911 & 0.8867 & 0.0053 & 0.9943 \\
\hline
\end{tabular}




\begin{tabular}{|c|c|c|c|c|c|c|c|c|c|}
\hline \multirow[t]{3}{*}{ Reconstituted } & $\begin{array}{l}0 \% \\
\text { FT }\end{array}$ & 0.0035 & 0.9993 & $0.0054^{\mathrm{b}}$ & 0.0041 & 0.9992 & 0.9478 & 0.0052 & 0.9973 \\
\hline & $\begin{array}{l}2 \% \\
\text { FT }\end{array}$ & 0.0031 & 0.9984 & $0.0045^{b}$ & 0.0035 & 0.9981 & 0.9130 & 0.0054 & 0.9923 \\
\hline & $\begin{array}{l}4 \% \\
\text { FT }\end{array}$ & 0.0025 & 0.9967 & $0.0091^{\mathrm{c}}$ & 0.0029 & 0.9989 & 0.8977 & 0.0057 & 0.9891 \\
\hline \multicolumn{10}{|c|}{ Mango juice } \\
\hline \multirow{4}{*}{ Fresh } & $\begin{array}{c}\mathrm{N} / \\
\mathrm{A}\end{array}$ & 0.0031 & 0.9935 & $0.0215^{\mathrm{a}}$ & 0.0028 & 0.9965 & 0.9046 & 0.0055 & 0.9968 \\
\hline & $\begin{array}{l}0 \% \\
\text { FT }\end{array}$ & 0.0030 & 0.9915 & $0.0177^{\mathrm{b}}$ & 0.0031 & 0.9943 & 0.8311 & 0.0078 & 0.9875 \\
\hline & $\begin{array}{l}2 \% \\
\text { FT }\end{array}$ & 0.0029 & 0.9937 & $0.0217^{\mathrm{b}}$ & 0.0029 & 0.9931 & 0.8197 & 0.0081 & 0.9849 \\
\hline & $\begin{array}{l}4 \% \\
\text { FT }\end{array}$ & 0.0030 & 0.9889 & $0.0256^{b}$ & 0.0032 & 0.9963 & 0.8049 & 0.0087 & 0.9983 \\
\hline \multirow[t]{3}{*}{ Reconstituted } & $\begin{array}{l}0 \% \\
\text { FT }\end{array}$ & 0.0033 & 0.9965 & $0.0149^{a}$ & 0.0036 & 0.9989 & 0.8953 & 0.0067 & 0.9923 \\
\hline & $\begin{array}{l}2 \% \\
\text { FT }\end{array}$ & 0.0032 & 0.9952 & $0.0173^{\mathrm{b}}$ & 0.0033 & 0.9973 & 0.8875 & 0.0054 & 0.9957 \\
\hline & $\begin{array}{l}4 \% \\
\text { FT }\end{array}$ & 0.0026 & 0.9976 & $0.0083^{c}$ & 0.0027 & 0.9995 & 0.9143 & 0.0049 & 0.9997 \\
\hline
\end{tabular}

FT: Fructans, N/A: no additives. All samples contain $10 \%$ maltodextrin.

Note: Group means with the same letters in a column are significantly different at $5 \%$ level of significant by Tukey test.

Table 1. Experimental data fitted to parameters of rheological models (Newtonian, Bingham and Power Law).

from $0.0145 \mathrm{~Pa}$ (fresh juice) to $0.0029 \mathrm{~Pa}$. The addition of maltodextrin to chayote and carrot juice induces a significant decrease of the yield stress of juice. This effect may be attributed to the interactions between the maltodextrin and the other polysaccharides, which do not allow these polysaccharides to fully extend in solution [30]. According to Grabowski et al. 2008 who studied the rheological properties of spray-dried sweet potato-maltodextrin powders, maltodextrin polysaccharide interactions could induce a decrease of the viscosity, since longer molecules have a larger hydrodynamic volume, which increases solution viscosity.

The additional supplementation of fructans up to $4 \%$ induced a slight but significant increase of the yield stress of fresh chayote juice up to $0.0078 \mathrm{~Pa}$. Furthermore, spray drying did not seem to deeply impact the rheological behavior of chayote juices (Table 1). Pineapple juices presented higher yield stresses than chayote, while they had the same plastic viscosity. These findings could be because fruit juices contain colloidal systems. These colloids are part of the fruit itself or may be formed by microorganisms during fruit ripening. Most of the colloids come from the plant itself. The amount of colloids present in fruit juice is in the range of $100-1000 \mathrm{mg} / \mathrm{L}$. An examination of colloids in the juice after pressing shows that they are basically polysaccharides such as pectins and starch [31, 32]. In this sense, the pineapple contains 


\begin{tabular}{|c|c|c|c|}
\hline \multicolumn{2}{|c|}{ Sample } & \multicolumn{2}{|c|}{ Flow parameters } \\
\hline & & $\tau_{0}$ & $\eta^{\prime}$ \\
\hline & N/A & $0.0145 \pm 0.0017^{a}$ & $0.0030 \pm 0.0003^{a}$ \\
\hline Fresh & $0 \% \mathrm{FT}$ & $0.0029 \pm 0.0002^{b}$ & $0.0032 \pm 0.0004^{a}$ \\
\hline \multirow[t]{2}{*}{ Chayote } & $2 \% \mathrm{FT}$ & $0.0062 \pm 0.0002^{c}$ & $0.0033 \pm 0.0008^{a}$ \\
\hline & $4 \% \mathrm{FT}$ & $0.0078 \pm 0.0006^{c}$ & $0.0032 \pm 0.0007 \mathrm{a}$ \\
\hline Reconstituted & $0 \%$ FT & $0.0039 \pm 0.0002^{b}$ & $0.0029 \pm 0.0004^{a}$ \\
\hline \multirow[t]{3}{*}{ Chayote } & $2 \% \mathrm{FT}$ & $0.0042 \pm 0.0003^{b}$ & $0.0029 \pm 0.0001^{\mathrm{a}}$ \\
\hline & $4 \% \mathrm{FT}$ & $0.0091 \pm 0.0004^{\mathrm{d}}$ & $0.0029 \pm 0.0003^{a}$ \\
\hline & N/A & $0.0266 \pm 0.0021^{a}$ & $0.0026 \pm 0.0002^{a}$ \\
\hline Fresh & $0 \%$ FT & $0.0301 \pm 0.0006^{b}$ & $0.0029 \pm 0.0002^{a}$ \\
\hline \multirow[t]{2}{*}{ Pineapple } & $2 \% \mathrm{FT}$ & $0.0354 \pm 0.0017^{\circ}$ & $0.0029 \pm 0.0001^{a}$ \\
\hline & $4 \% \mathrm{FT}$ & $0.0432 \pm 0.0013^{c}$ & $0.0027 \pm 0.0001^{a}$ \\
\hline Reconstituted & $0 \%$ FT & $0.0216 \pm 0.0028^{a}$ & $0.0026 \pm 0.0002^{a}$ \\
\hline \multirow[t]{3}{*}{ Pineapple } & $2 \% \mathrm{FT}$ & $0.0310 \pm 0.0011^{b}$ & $0.0027 \pm 0.0003^{a}$ \\
\hline & $4 \% \mathrm{FT}$ & $0.0087 \pm 0.0025^{d}$ & $0.0028 \pm 0.0001^{a}$ \\
\hline & N/A & $0.0152 \pm 0.0010^{a}$ & $0.0035 \pm 0.0005^{a}$ \\
\hline Fresh & $0 \% \mathrm{FT}$ & $0.0036 \pm 0.0012^{b}$ & $0.0037 \pm 0.0004^{a}$ \\
\hline \multirow[t]{2}{*}{ Carrot } & $2 \% \mathrm{FT}$ & $0.0075 \pm 0.0009$ & $0.0036 \pm 0.0006^{a}$ \\
\hline & $4 \% \mathrm{FT}$ & $0.0082 \pm 0.0005^{c}$ & $0.0031 \pm 0.0011^{a}$ \\
\hline Reconstituted & $0 \%$ FT & $0.0042 \pm 0.0003^{b}$ & $0.0031 \pm 0.0002^{a}$ \\
\hline \multirow[t]{3}{*}{ Carrot } & $2 \% \mathrm{FT}$ & $0.0056 \pm 0.0006^{b}$ & $0.0033 \pm 0.0005^{\mathrm{a}}$ \\
\hline & $4 \% \mathrm{FT}$ & $0.0098 \pm 0.0006^{d}$ & $0.0032 \pm 0.0004^{a}$ \\
\hline & N/A & $0.0311 \pm 0.0011^{a}$ & $0.0025 \pm 0.0003^{a}$ \\
\hline Fresh & $0 \% \mathrm{FT}$ & $0.0402 \pm 0.0016^{b}$ & $0.0022 \pm 0.0001^{\mathrm{a}}$ \\
\hline \multirow[t]{2}{*}{ Mango } & $2 \%$ FT & $0.0461 \pm 0.0021^{b}$ & $0.0026 \pm 0.0007$ \\
\hline & $4 \% \mathrm{FT}$ & $0.0512 \pm 0.0003^{c}$ & $0.0029 \pm 0.0008^{\mathrm{a}}$ \\
\hline Reconstituted & $0 \%$ FT & $0.0318 \pm 0.0009^{a}$ & $0.0025 \pm 0.0006^{a}$ \\
\hline \multirow[t]{2}{*}{ Mango } & $2 \% \mathrm{FT}$ & $0.0223 \pm 0.0012^{b}$ & $0.0029 \pm 0.0005^{a}$ \\
\hline & $4 \%$ FT & $0.0156 \pm 0.0015^{d}$ & $0.0031 \pm 0.0011^{a}$ \\
\hline
\end{tabular}

Note: Values follow by the same letter within the same row are notsignificantly different from each other $(\mathrm{p}>0.05)$

Table 2. Influence of fructans addition and spray-drying on yield stress $\left(\tau_{0^{\prime}}\right.$ pa) and plastic viscosity $\left(\eta^{\prime}\right.$, pa.S) of juices.

more pectins than chayote, carrot and mango, and pectins are responsible for the turbidity and high viscosity of fruit juices. The addition of maltodextrin and fructans up to $4 \%$ [w/v] also induced a slight but significant increase of the yield stress of pineapple juices. However, 
a decrease of this rheological parameter was observed for reconstituted juices after spray drying especially for samples with $4 \%$ of fructans, which could be due to the solubility of fructans above $95 \%$ [10].

The viscosity of agave fructans solutions (Agave tequilana Weber blue var.) at different concentrations and temperatures has been studied by Ponce et al. [20]. They observed that solutions with concentrations inferior to $30 \%[\mathrm{w} / \mathrm{v}]$ at temperatures ranging between 30 and $60^{\circ} \mathrm{C}$ presented a low viscosity, similar to water. Meanwhile, the viscosity of solutions with concentrations superior or equal to $30 \%[\mathrm{w} / \mathrm{v}]$, increased when increasing the concentration up to $70 \%$, forming a highly viscous fluid. The results obtained in this work are in agreement with previous findings; lower plastic viscosity was observed in fructans powders with lower concentrations, this according to the flow parameters such as plastic viscosity $\left(\eta^{\prime}\right)$ and yield stress $\left(\tau_{0}\right)$ obtained with Eq. 2. This shear thinning behavior at low shear rate $\left(20 \mathrm{~s}^{-1}\right)$ followed by thickening behavior at high shear rate $\left[300 \mathrm{~s}^{-1}\right]$ in low fructans concentrations $\left(\mathrm{C}_{\text {fructans }} \leq 30 \%\right.$ in weight $)$ could be due to flow instabilities such as vortices, since the viscosity of the samples is close to that of water [33].

The effect of adding maltodextrin on tomato pulp during spray-drying has been studied by Goula and Adamopoulos [30]. They observed that reconstituted tomato pulp from the resulting powder showed a non-Newtonian behavior with low stress, and a decrease in viscosity when the maltodextrin concentration and dextrose equivalent increase. This same effect is observed in the reconstituted chayote and pineapple powders and is attributed to the fact that the $10 \%$ maltodextrin concentration is higher in comparison to that of fructans.

Chayote, carrot, mango and pineapple juices [fresh and reconstituted] did not present the same rheological behavior [specially for the yield stress]. In this sense, studies have found that a decrease in sweet-potato solids, as well as interaction between maltodextrin and sweetpotato polysaccharides contributed to a decrease in viscosity of the reconstituted purée [34]. In general, the flow behavior of fresh and reconstituted sweet-potato solutions was different suggesting that the solids concentration being modified by the molecular changes during spray-drying. This could also explain the distinct rheological behavior for each reconstituted fruit powder in the present study.

\section{Conclusions}

The addition of native agave fructans contributes to a significant decrease in the mass fraction of maltodextrin added in this type of industrial products. All fresh or reconstituted juices present a flow behavior typical of plastic fluids [Bingham model]. The addition of maltodextrin $[10 \%$ ] and fructans [up to $4 \%$ ] as well as the step of spray-drying did not change significantly the plastic viscosity of juices. Only the yield stresses, which represent the behavior of fluids at rest, were impacted by these parameters. The combination of native agave fructans with maltodextrin as a stabilizer produced spherical particles with shrinkage, lumps, and caking between them. The flow behavior as a function of concentration indicates that the agave native fructans and the fructans-maltodextrin mixtures behave similar to simple sugars but with an increase in the viscosity of the mixture. 


\section{Acknowledgements}

The authors thank CONACyT [México] for their support in conducting the work throughout project number 210874 and for the scholarship granted to Jimenez-Sanchez D. E.

\section{Author details}

Darvin Ervey Jimenez-Sánchez ${ }^{1}$, Montserrat Calderón-Santoyo ${ }^{1}$, Laetitia Picart-Palmade ${ }^{2}$, Pedro Ulises Bautista Rosales ${ }^{3}$, Julio Cesar Barros-Castillo ${ }^{1}$ and Juan Arturo Ragazzo-Sánchez ${ }^{1 *}$

*Address all correspondence to: jragazzo@ittepic.edu.mx

1 Laboratorio Integral de Investigación en Alimentos, Tecnológico Nacional de MéxicoInstituto Tecnológico de Tepic, Tepic, Nayarit, México

2 Université de Montpellier, UMR 1208, Ingénierie des Agropolymères et Technologies Emergentes, Place Eugène Bataillon, Montpellier, France

3 Centro de Tecnología de Alimentos, Universidad Autónoma de Nayarit, Ciudad de la Cultura "Amado Nervo", Tepic, Nayarit, México

\section{References}

[1] Juszczak L, Witczak M, Fortuna T, Solarz B. Effect of temperature and soluble solids content on the viscosity of beetroot [Beta vulgaris] juice concentrate. International Journal of Food Properties. 2010;13(6):1364-1372

[2] Rao A. Rheology of Fluid, Semisolid, and Solid Foods: Principles and applications. Rheology Fluid, Semisolid, Solid Foods. 2013;19:461

[3] Magerramov MA, Abdulagatov AI, Azizov ND, Abdulagatov IM. Effect of temperature, concentration, and pressure on the viscosity of pomegranate and pear juice concentrates. Journal of Food Engineering. 2007;80(2):476-489

[4] Tiziani S, Vodovotz Y. Rheological effects of soy protein addition to tomato juice. Food Hydrocolloids. 2005;19(1):45-52

[5] Aguiló-Aguayo I, Oms-Oliu G, Soliva-Fortuny R, Martín-Belloso O. Changes in quality attributes throughout storage of strawberry juice processed by high-intensity pulsed electric fields or heat treatments. LWT- Food Science and Technology. 2009;42(4):813-818

[6] Bhandari BR, Senoussi A, Dumoulin ED, Lebert A. Spray drying of concentrated fruit juices spray drying of concentrated fruit juices. An International Journal Drying Technology. 1993;11(55):10811092 
[7] Fernandes RVB, Borges SV, Botrel DA. Influence of spray drying operating conditions on microencapsulated rosemary essential oil properties I Influência das condições operacionais da secagem por atomização nas propriedades de óleo de alecrim microencapsulado. Ciência e Tecnologia de Alimentos. 2013;33(SUPPL. 1):171-178

[8] Shrestha AK, Ua-Arak T, Adhikari BP, Howes T, Bhandari BR. Glass transition behavior of spray dried orange juice powder measured by differential scanning calorimetry [DSC] and thermal mechanical compression test [TMCT]. International Journal of Food Properties. 2007;10(3):661-673

[9] QuekSY,ChokNK, SwedlundP. The physicochemical properties of spray-dried watermelon powders. Chemical Engineering and Processing Process Intensification. 2007;46(5):386-392

[10] Espinosa-Andrews H, Urias-Silvas JE. Thermal properties of agave fructans [Agave tequilana Weber var. Azul]. Carbohydrate Polymers [Internet]. Elsevier Ltd. 2012;87(4): 2671-2676 Available from: http://dx.doi.org/10.1016/j.carbpol.2011.11.053

[11] Roberfroid MB, Delzenne NM. Dietary fructans. Annual Review of Nutrition. 1998;18: 117-143

[12] Arvidson SA, Rinehart BT, Gadala-Maria F. Concentration regimes of solutions of Levan polysaccharide from Bacillus sp. Carbohydrate Polymers. 2006;65(2):144-149

[13] Trumbo P, Schlicker S, Yates AA, Poos M. Dietary reference intakes for energy, carbohydrate, fiber, fat, fatty acids, cholesterol, protein and amino acids. Journal of the American Dietetic Association. 2002;102:1621-1630

[14] Franck A. Technological functionality of inulin and oligofructose. British Journal of Nutrition [Internet]. 2002;87(6):287-291 Available from: http://www.ingentaselect.com/ $\mathrm{rpsv} /$ cgi-bin/cgi?ini=xref\&body=linker\&reqdoi=10.1079/BJNBJN/2002550

[15] Botrel DA, Borges SV, Fernandes RVDB, Lourenço Do Carmo E. Optimization of fish oil spray drying using a protein: Inulin system. Drying Technology. 2014;32(3):279-290

[16] Chávez-Rodríguez A, López-Muraira IG, Goméz-Leyva JF, Luna-Solano G, OrtízBasurto RI, Andrade-González I. Optimization of Agave tequilana Weber var. Azul juice spray drying process. Journal of Chemistry. 2014;2014

[17] Vereyken IJ, Chupin V, Demel RA, Smeekens SCM, De Kruijff B. Fructans insert between the headgroups of phospholipids. Biochimica et Biophysica Acta, Biomembranes. 2001;1510(1-2):307-320

[18] Harte F, Clark S, Barbosa-Cánovas GV. Yield stress for initial firmness determination on yogurt. Journal of Food Engineering. 2007;80(3):990-995

[19] Guggisberg D, Cuthbert-Steven J, Piccinali P, Bütikofer U, Eberhard P. Rheological, microstructural and sensory characterization of low-fat and whole milk set yoghurt as influenced by inulin addition. International Dairy Journal. 2009;19(2):107-115

[20] Ponce SJA, Macías BER, Soltero MJFA, Fern_andez EVV, Zúniga PV, Escalona BHB. Physical-Chemical and non-linear rheological properties of aqueous solutions of agave fructans Propiedades fisicoquímicas y reología no lineal de soluciones acuosas de fructanos de agave. 2008;6:1-23 
[21] Soltero JFA, Alvarez-Ramírez JG, Fernández VVA, Tepale N, Bautista F, Macías ER, et al. Phase and rheological behavior of the polymerizable surfactant CTAVB and water. Journal of Colloid and Interface Science. 2007;312(1):130-138

[22] Donnelly RJ, Simon NJ. An empirical torque relation for supercritical flow between rotating cylinders. Journal of Fluid Mechanics. 1960;7(3):401-418

[23] Cole JA. Taylor-vortex instability and annulus-length effects. Journal of Fluid Mechanics. 1976;75(1):1-15

[24] Baumert BM, Muller SJ. Axisymmetric and non-axisymmetric elastic and inertio-elastic instabilities in Taylor-Couette flow. Journal of Non-Newtonian Fluid Mechanics. 1999; 83(1-2):33-69

[25] Li Z, Khayat RE. Pattern formation in weakly forced Taylor-Couette flow. Phys rev E stat physics, plasmas, fluids. Related Interdisciplinary topics. 2004;69(4):9

[26] Macias ER, Gonzalez A, Manero O, Gonzales-Nunez R, Soltero JFA, Attané P. Flow regimes of dilute surfactant solutions. Journal of Non-Newtonian Fluid Mechanics. 2001;101(1-3):149-171

[27] Raspaud E, Lairez D, Adam M. On the number of blobs per entanglement in Semidilute and good solvent solution: Melt influence. Macromolecules. 1995;28(4):927-933

[28] Sosa-Herrera MG, Martínez-Padilla LP, Delgado-Reyes VA, Torres-Robledo A. Effect of agave fructans on bulk and surface properties of sodium caseinate in aqueous media. Food Hydrocolloids. 2016;60:199-205

[29] Shamsudin R, Ling CS, Adzahan NM, Daud WRW. Rheological properties of ultraviolet-irradiated and thermally pasteurized Yankee pineapple juice. Journal of Food Engineering. 2013;116(2):548-553

[30] Goula AM, Adamopoulos KG. Effect of Maltodextrin Addition during Spray Drying of Tomato Pulp in Dehumidified Air: I. Drying Kinetics and Product Recovery. Dry Technology [Internet]. 2008;26(6):714-725 Available from: http://www.tandfonline.com/ doi/abs/10.1080/07373930802046369

[31] Barros STD, Mendes ES, Peres L. Influence of depectinization in the ultrafiltration of West Indian cherry [Malpighia glabra L.] and pineapple [Ananas comosus [L.] Meer] juices. Ciência e Tecnologia de Alimentos [Internet]. 2004;24(2):194-201 Available from: http:// search.epnet.com/login.aspx?direct=true\&db=lah\&an=20043117754

[32] Echavarría AP, Falguera V, Torras C, Berdún C, Pagán J, Ibarz A. Ultrafiltration and reverse osmosis for clarification and concentration of fruit juices at pilot plant scale. LWT- Food Science and Technology. 2012;46(1):189-195

[33] Macías-Rubalcava ML, Hernández-Bautista BE, Jiménez-Estrada M, Cruz-Ortega R, Anaya AL. Pentacyclic triterpenes with selective bioactivity from Sebastiania adenophora leaves, euphorbiaceae. Journal of Chemical Ecology. 2007;33(1):147-156

[34] Grabowski JA, Truong V, Daubert CR. Nutritional and rheological characterization of spray dried sweetpotato powder. 2008;41:206-216 
